\title{
Article \\ Study of Indicators of CI Engine Running on Conventional Diesel and Chicken Fat Mixtures Changing EGR
}

\author{
Alfredas Rimkus ${ }^{1,2}{ }^{\oplus}$, Tadas Vipartas ${ }^{1}$, Jonas Matijošius ${ }^{1,2, *} \mathbb{C}$, Saulius Stravinskas ${ }^{1,2}$ and Donatas Kriaučiūnas ${ }^{1}$ \\ 1 Department of Automobile Transport Engineering, Technical Faculty, Vilnius College of \\ Technologies and Design, Olandu Str. 16, LT-01100 Vilnius, Lithuania; a.rimkus@vtdko.lt (A.R.); \\ t.vipartas@vtdko.lt (T.V.); s.stravinskas@vtdko.lt (S.S.); d.kriauciunas@vtdko.lt (D.K.) \\ 2 Department of Automobile Engineering, Faculty of Transport Engineering, Vilnius Gediminas \\ Technical University, J. Basanavičiaus Str. 28, LT-03224 Vilnius, Lithuania \\ * Correspondence: jonas.matijosius@vilniustech.lt; Tel.: +370-684-041-69
}

check for updates

Citation: Rimkus, A.; Vipartas, T.; Matijošius, J.; Stravinskas, S.;

Kriaučiūnas, D. Study of Indicators of CI Engine Running on Conventional Diesel and Chicken Fat Mixtures Changing EGR. Appl. Sci. 2021, 11, 1411. https://doi.org/10.3390/ app11041411

Academic Editor: Nag Jung Choi

Received: 8 January 2021

Accepted: 28 January 2021

Published: 4 February 202

Publisher's Note: MDPI stays neutral with regard to jurisdictional claims in published maps and institutional affiliations.

Copyright: (c) 2021 by the authors. Licensee MDPI, Basel, Switzerland This article is an open access article distributed under the terms and conditions of the Creative Commons Attribution (CC BY) license (https:// creativecommons.org/licenses/by/ $4.0 /)$.

\begin{abstract}
This article presents a change in the indicators of a compression ignition (CI) engine by replacing conventional diesel fuel (D100) with pure chicken fat (F100) and mixtures of these fuels. Mixtures of diesel and fat with volume ratios of 70/30,50/50 and 30/70 were used. Research of the fuel properties was conducted. In order to reduce the fuel viscosity, blends of fat and diesel were heated. The experimental research was conducted at different engine loads with exhaust gas recirculation (EGR) both off and on. The conducted analysis of the combustion process revealed a significant change in the rate of heat release (ROHR) when replacing diesel with chicken fat. Chicken fat was found to increase the $\mathrm{CO}_{2}$ and $\mathrm{CO}$ emissions, leaving hydrocarbon (HC) emissions nearly unchanged. Having replaced the D100 with diesel and chicken fat mixtures or F100, a significant reduction in smoke and nitrogen oxide $\left(\mathrm{NO}_{\mathrm{x}}\right)$ emissions was observed when EGR was off. When EGR was on, the smoke level increased, but the blends with chicken fat reduced it significantly, and the increased fat content in the fuel mixture reduced the $\mathrm{NO}_{\mathrm{x}}$ emissions. The engine's brake specific fuel consumption (BSFC) increased while the brake thermal efficiency (BTE) decreased, having replaced conventional diesel with chicken fat due to differences in the fuel energy properties and the combustion process.
\end{abstract}

Keywords: conventional diesel; chicken fat; combustion; pollutant emissions; engine efficiency

\section{Introduction}

Climate change and its effects have been reflected in human activities related to both mobility and the reduction of environmental pollution [1]. The European Union's Transport White Paper lays down the guidelines for reducing environmental pollution without reducing the concept of mobility and for promoting the rational use of energy resources [2,3]. When it comes to cars running on conventional fuel, diesel cars are discussed most widely because of their high emissions of particulate matter (PM) [4]. Diesel vehicles have been very popular worldwide in recent decades [5] due to their lower fuel consumption compared with petrol [6] or liquified petroleum gas vehicles [7]. However, with environmental requirements (EURO pollution requirements in the European Union) becoming more stringent, they have become problematic for their high emissions of particulate matter [8]. Technological solutions (such as diesel particulate filters (DPFs)) as well as new types of fuel that emit less PM during combustion [9-11] have been used as solutions to reduce pollution.

Using a substitute of biological origin (biodiesel) for conventional diesel allows for achieving significant pollution improvement benefits, manifesting in the reduced emissions of PM, CO and hydrocarbons (HCs) compared with diesel [12]. It should be noted that the level of pollution reduction may vary, depending on whether biodiesel or another type of biofuel is used and the percentage of its replaceability in the fuel mixture, disregarding 
engine operating modes [13]. Thus, it is very important to choose the right type of biofuel and its replaceability percentage share in fuel mixtures [14].

The following key aspects in choosing the type of biofuel were distinguished in this article [15]: the availability of raw materials [16]; that local raw materials must be used as fuel [17] in order to maximize the economic benefit and energy independence from the market of conventional fuels [18]; the compatibility of raw materials; and their adaptability to currently used internal combustion engines [19]. Chicken fat meets these requirements. Lithuania has a well-developed meat processing industry, which produces (especially when it comes to chicken) large amounts of fat, a cheap and high-energy raw material [20]. Its further use can be related to the chemical industry [21], but it can also be used as fuel in compression ignition engines [22], especially considering the fact that industrial waste has already been used for similar purposes before (e.g., waste fat from the leather industry was used in fuel production). The received test results showed the applicability of ester blends of this raw material with diesel ( $10 \%$ and $30 \%$ ester in diesel), as the cetane number of the blends for the in-cylinder pressure and heat release curves were very similar to those of diesel. It should be noted that the previously discussed ecological effect was observed in the form of lower PM [23] and NOx emissions [24]. The lower heating value (LHV) of fat is lower than that of diesel, and when using animal fats as fuel, an increase in the brake specific fuel consumption and a decline in the brake thermal efficiency occurs because of the changing combustion process [25]. These results were obtained using fatty esters, as the complexity of the production process (which requires nanocatalysts such as $\mathrm{CaO} / \mathrm{CuFe}_{2} \mathrm{O}_{4}$ ) [26] does not allow their widespread use as waste raw materials, and further processing of them is necessary. The results received from simulations (two models based on neutron grids and a genetic algorithm were used) revealed rates of pollution which would be generated by a EURO 4-compliant diesel engine running on mixtures of animal fats and diesel. The numerical research revealed that the use of such mixtures was possible in a diesel engine, and the correspondence of results according to the $\mathrm{R}^{2}$ values varied for different pollutants (most accurately for $\mathrm{CO}(0.93)$ and least accurately for $\mathrm{CO}_{2}$ and $\mathrm{NO}_{\mathrm{x}}(0.4$ and 0.41 , respectively)) [27]. When using chicken fat as fuel, several aspects to be assessed can be distinguished [28], including the combustion process, exhaust emissions and energy parameters.

When it comes to the combustion process, the use of chicken fat and its mixtures with diesel led to a reduced rate of heat release due to the cooling effect of fuel evaporation. At a $100 \%$ load, the rate of heat release (ROHR) reduced from $70 \mathrm{~J} /$ degree (diesel) to $63 \mathrm{~J} /$ degree (25\% chicken fat content in diesel). The same trend was observed in the case of the maximum in-cylinder pressure, measured as $7.0 \mathrm{MPa}$ (diesel) and $6.8 \mathrm{MPa}(25 \%$ chicken fat in diesel) [29]. It was also observed that the homogeneous charge compression ignition (HCCI) engine effect (where combustion is achieved at a temperature below the $\mathrm{NO}_{x}$ formation temperature) can be achieved when using chicken fat. Thus, the author suggested using chicken fat for low and partial loads only. Having increased the load, the engine worked as a normal compression ignition engine [30]. Increasing the content of the chicken fat in diesel led to a decrease in the exhaust gas temperature. Larger fuel droplets and their lower acceleration caused the temperature decrease [31].

The use of chicken fat resulted in lower $\mathrm{NO}_{\mathrm{x}}$ emissions compared with diesel fuel, both during their generation [32] and combustion [33]. A noticeable reduction in $\mathrm{CO}$ and $\mathrm{HC}$ emissions compared with conventional diesel [34] and higher $\mathrm{CO}_{2}$ emissions were observed, due to higher oxygen concentrations in the fat and diesel mixture [35]. Like all types of biodiesel presented in this reference work, chicken fat reduces PM emissions; in separate tests, PM emissions could decrease up to $65 \%$ compared with diesel [36].

Analysis of the energy aspects of the use of chicken fat revealed a lower brake thermal efficiency (BTE) indicator as a result of a higher fat viscosity, changed combustion process and the previously described higher brake specific fuel consumption (BSFC), forming for the same reasons as in case of the BTE [29]. The same trend was observed when analyzing 
turkey fat and diesel mixtures in a compression ignition engine [24]. Engine power using chicken fat also decreases, depending on the fat content in the fuel mixtures [37].

In summary, it can be concluded that there are relatively few studies on the indicators of compression ignition engines running on mixtures of chicken fat and diesel compared with other alternative fuels (e.g., biodiesel and hydrogen). These studies were observed to not use the exhaust gas recirculation (EGR) system. Therefore, research of the properties of diesel and chicken fat mixtures and analysis of the combustion process of compression ignition engines, as well as their environmental and energy indicators with EGR on and off, would allow for the expansion of the scientific area of application of these fuel mixtures.

\section{Equipment, Methodology and Fuel}

A comparative study of engine performance was conducted using a compression ignition engine (AUDI, 1.9 TDI, 1z) controlled by an electronic control unit (ECU). Fuel was supplied to the engine using a BOSCH VP37 axial piston distributor type injection pump and two spring hole type nozzle injectors. Air was supplied using a turbocharger. The engine was equipped with an exhaust gas recirculation (EGR) system. Table 1 presents the key engine data.

Table 1. The main parameters of the compression ignition engine.

\begin{tabular}{cc}
\hline Parameter & Value \\
\hline Displacement & $1986 \mathrm{~cm}^{3}$ \\
Number of cylinders & 4 \\
Compression ratio & 19.5 \\
Piston diameter & $79.5 \mathrm{~mm}$ \\
Piston stroke & $95.5 \mathrm{~mm}$ \\
Power & $66 \mathrm{~kW}(4000 \mathrm{rpm})$ \\
Torque & $182 \mathrm{Nm}(2000-2500 \mathrm{rpm})$ \\
Fuel injection & Direct \\
Pressure of the opening of the fuel injector & $190 \mathrm{bar}$ \\
\hline
\end{tabular}

A diagram of the equipment used in the experimental research is presented in Figure 1. For the engine load, the brake torque $M_{B}$ was measured using the KI-5543 load bench (accuracy of measurement $=1.2 \mathrm{Nm}$ ). Fuel consumption was determined using the SK-5000 scale (accuracy of measurement $=1.0 \mathrm{~g}$ ) and a stopwatch. The intake air mass was measured using the BOSCH HFM 5 air mass meter (accuracy $\leq 2 \%$ ). For the fuel injection timing, the start of injection (SOI) was determined using VAG-COM diagnostic equipment connected to the ECU On-board diagnostics (OBD) connector. A needle lift sensor integrated in the fuel injector generated SOI information. The in-cylinder pressure was measured using a glow plug adapter with an AVL GH13P integrated piezo pressure sensor, with its sensitivity/linearity at $250^{\circ} \mathrm{C}$ being 15.88 (pC/bar)/ \pm 0.11 (\%Fast Cookoff Sensor (FCO)) The crankshaft position was determined using an A58M-F encoder (accuracy $=0.1758$ crank angle degrees (CAD)). The 100 cycle in-cylinder pressure and CAD data were transmitted using an AVL DiSTEST DPM 800 oscilloscope and recorded using LabView Real software. The pressure in the engine intake manifold was measured using a Delta OHM HD 2304.0 and a TP704-2BAI sensor (accuracy $= \pm 0.0002 \mathrm{MPa}$ ). A Type K thermocouple with an accuracy of $\pm 0.5 \%$ was used to measure the intake air and the exhaust gas temperature. The concentrations of various components (carbon dioxide $\left(\mathrm{CO}_{2}\right)$, carbon monoxide $(\mathrm{CO})$, hydrocarbons (HCs), nitrogen oxides $\left(\mathrm{NO}_{\mathrm{x}}\right)$ and the smoke absorption coefficient) in the exhaust gas were measured using an AVL DiCom 4000 gas analyzer and the opacimeter. The gas analyzer accuracies were as follows: $0.1 \%$ vol. for $\mathrm{CO}_{2} ; 0.01 \%$ vol. for $\mathrm{CO} ; 1 \mathrm{ppm}$ for $\mathrm{HC}$; $1 \mathrm{ppm}$ for $\mathrm{NO}_{\mathrm{x}}$; and $0.01 \mathrm{~m}^{-1}$ for smoke. 


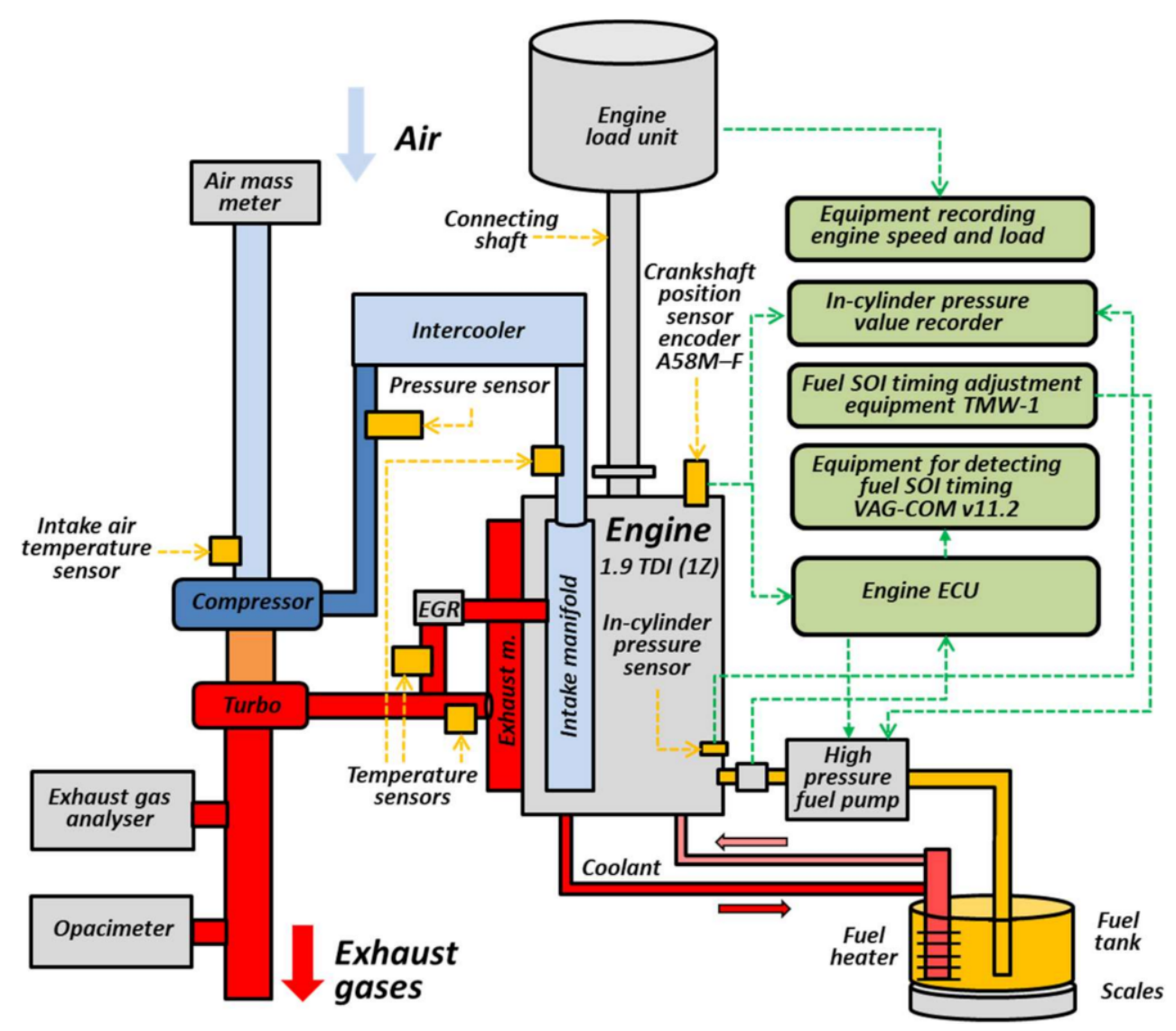

Figure 1. Engine test equipment.

The experimental research was conducted at a constant engine speed of $n=2000 \mathrm{rpm}$ and three different loads $\left(M_{B}=45 \mathrm{Nm}, M_{B}=60 \mathrm{Nm}\right.$ and $\left.M_{B}=90 \mathrm{Nm}\right)$, corresponding to a brake mean effective pressure (BMEP) of $0.3 \mathrm{MPa}, 0.4 \mathrm{MPa}$ and $0.6 \mathrm{MPa}$, respectively. Engines operate in this mode when cars run at a speed of $\sim 50-100 \mathrm{~km} / \mathrm{h}$. Tests were also performed with EGR off and on. When conducting a test with EGR on, the ECU controlled the EGR valve; the EGR flow was set for assessing the intake air mass. At different engine loads (BMEP $=0.3 \mathrm{MPa}, 0.4 \mathrm{MPa}$ and $0.6 \mathrm{MPa}$ ), the EGR coefficient was $k_{E G R} *=0.27,0.26$ and 0.19 , respectively.

Numerical analysis of the combustion process was performed using the AVL BOOST software with the BURN utility. The rate of heat release (ROHR) was calculated during combustion according to cylinder pressure traces measured during the experiment, the fuel and air consumption, fuel properties and engine data, using the laws of thermodynamics and mechanics. The start of combustion (SOC), temperature, rise in temperature and rise in pressure in the cylinder were determined. These combustion process indicators provided additional information for analyzing the environmental and energy indicators of an engine running on conventional diesel and chicken fat fuel mixtures.

The experimental research was conducted with the engine running on conventional diesel (D100), chicken fat (F100) and diesel and chicken fat 70/30, 50/50 and $30 / 70$ (\% vol/\% vol) mixtures (labeled as D70F30, D50F50 and D30F70). The properties of the pure fuels were examined, and they are presented in Table 2. 
Table 2. Fuel properties.

\begin{tabular}{|c|c|c|c|c|c|}
\hline \multirow{2}{*}{\multicolumn{2}{|c|}{ Parameter, Units }} & \multirow{2}{*}{ Standard, Device } & \multirow{2}{*}{ Accuracy } & \multicolumn{2}{|c|}{ Fuel } \\
\hline & & & & D100 & F100 \\
\hline Gross heating valu & $/ \mathrm{kg}$ & LST CEN/TS 14918:2006 & \multirow{2}{*}{$0.13 \mathrm{MJ} / \mathrm{kg}$} & 45.3 & 39.3 \\
\hline Lower heating valu & $\mathrm{J} / \mathrm{kg}$ & IKA C 5000 calorimeter & & 42.5 & 37.6 \\
\hline \multicolumn{2}{|c|}{ Flash point, ${ }^{\circ} \mathrm{C}$} & $\begin{array}{c}\text { ISO 2719:2013 } \\
\text { FP93 5G2 Pensky-Martens analyzer }\end{array}$ & $0.03{ }^{\circ} \mathrm{C}$ & 67.1 & 120 \\
\hline \multirow{2}{*}{\multicolumn{2}{|c|}{$\begin{array}{c}\text { Kinematic viscosity at } 40^{\circ} \mathrm{C}, \mathrm{mm}^{2} / \mathrm{s} \\
\text { Density at } 40^{\circ} \mathrm{C}, \mathrm{kg} / \mathrm{m}^{3}\end{array}$}} & ASTM D7042, Anton Paar SVM 3000/G2 & $0.1 \%$ & 2.95 & 33.8 \\
\hline & & Stabinger viscometer & $0.0002 \mathrm{~g} / \mathrm{cm}^{3}$ & 819.8 & 880.8 \\
\hline \multicolumn{2}{|c|}{ Oxidative stability, min. } & EN 16091, PetroOXY analyzer & $0.1 \%$ & 56.6 & 15.5 \\
\hline \multicolumn{2}{|l|}{$\mathrm{CFPP},{ }^{\circ} \mathrm{C}$} & EN116; ASTMD6371, FPP 5Gs analyzer & $1^{\circ} \mathrm{C}$ & -22 & 26 \\
\hline \multicolumn{2}{|l|}{ WSD, $\mu \mathrm{m}$} & $\begin{array}{l}\text { ISO } 12156-1: 2006, \text { high-frequency } \\
\text { reciprocating rig method }\end{array}$ & $1 \mu \mathrm{m}$ & 404 & 271 \\
\hline \multicolumn{2}{|c|}{ Water content, $\%$ mass } & $\begin{array}{c}\text { ISO 12156-1:2006, } \\
\text { Aquamax KF Coulometric analyzer }\end{array}$ & $0.0003 \%$ & 0.004 & 0.153 \\
\hline \multicolumn{2}{|c|}{ Sulphur, \% mass } & IKA C 5000 calorimeter, muffle furnace, scales & $0.04 \%$ & \multicolumn{2}{|c|}{$\begin{array}{l}\text { Below the } \\
\text { detection limit }\end{array}$} \\
\hline \multirow{2}{*}{ Element composition } & $C, \%$ & Combusting the sample, separation of combustion & $0.01 \%$ & 86.23 & 77.10 \\
\hline & $\mathrm{H}, \%$ & gases and identification of components & $0.01 \%$ & 13.67 & 11.90 \\
\hline $\mathrm{C} / \mathrm{H}$ ratio & & & & 6.31 & 6.48 \\
\hline
\end{tabular}

When using conventional diesel and chicken fat mixtures, the fuel was heated to $\sim 50{ }^{\circ} \mathrm{C}$, because fuel viscosity increases at lower temperatures, clogging the fuel filter and significantly changing the fuel injection [38]. The fuel was heated using a heater connected to the engine cooling system. Fuel tests revealed that the lubricity property (wear scar diameter (WSD) testing) of F100 was not worse than that of the D100, and no additional lubricating additives were used.

Numerical analysis of the combustion process was performed using the AVL BOOST software with the BURN utility. The rate of heat release (ROHR) was calculated during combustion according to the cylinder pressure traces measured during the experiment, as well as the fuel and air consumption, fuel properties and engine data by using the laws of thermodynamics and mechanics. The start of combustion (SOC), temperature, rise in temperature and rise in pressure in the cylinder were determined. These combustion process indicators provided additional information for analyzing the environmental and energy indicators of an engine running on conventional diesel and chicken fat fuel mixtures.

\section{Research Results and Discussion}

A graphical diagram of the changes in the environmental and energy indicators and a discussion of the trends of the changes in the indicators, based on fuel properties, the numerical analysis of the combustion process and the conclusions of other researchers, were presented based on the results of the experimental research of a compression ignition (CI) engine running on pure conventional diesel (D100), pure chicken fat (F100) and D70F30, D50F50 and D30F70 mixtures.

\subsection{Combustion Indicators}

Numerical analysis was conducted using AVL BOOST software with the BURN utility, running on different fuels with EGR off and on when $n=2000 \mathrm{rpm}$ and BMEP $=0.4 \mathrm{MPa}$.

Figure 2, which illustrates the rate of heat release during combustion, allows stating that the start of combustion (SOC) of all the fuels and their mixtures was 3 CAD after top dead center (ATDC). The ECU was used to set the start of injection (SOI) to 1 CAD before top dead center (BTDC) in this engine operating mode, which suggests that the 
duration of the ignition delay phase of all the fuels was similar and was about 4 CAD. In the premixed combustion phase, the maximum ROHR value was achieved using pure diesel (EGR Off $=37.6 \mathrm{~J} / \mathrm{CAD}$ at 9 CAD ATDC, and EGR On $=30.0 \mathrm{~J} / \mathrm{CAD}$ (a decrease of $\sim 21 \%$ ) at 9 CAD ATDC). Having increased the chicken fat concentration to $30 \%, 50 \%, 70 \%$ and $100 \%$ in the premixed combustion phase with EGR being off, the ROHR decreased by $\sim 11 \%, \sim 17 \%, \sim 21 \%$ and $\sim 27 \%$, respectively, and with EGR being on, the ROHR decreased by $\sim 12 \%, \sim 16 \%, \sim 17 \%$ and $\sim 22 \%$, respectively. The increase in chicken fat concentration in the fuel was observed to shift the ROHR to a later combustion, and the diffusion phase was more intensive. With the engine running on diesel, the maximum ROHR value in the diffusion phase was at 29.5 J/CAD with EGR off and 28.1 J/CAD with EGR on. After increasing the chicken fat concentration to $100 \%$, the maximum ROHR of the diffusion phase increased up to $\sim 8 \%$ with EGR off and up to $\sim 5 \%$ with EGR on. Animal fat contains more heavy compounds, which do not evaporate or burn easily. Thus, combustion takes place at a later phase.

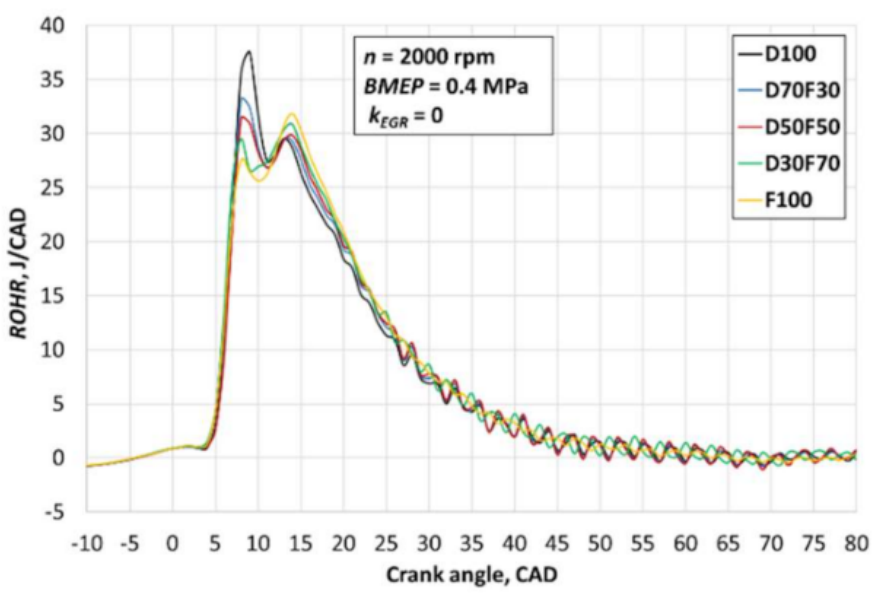

(a)

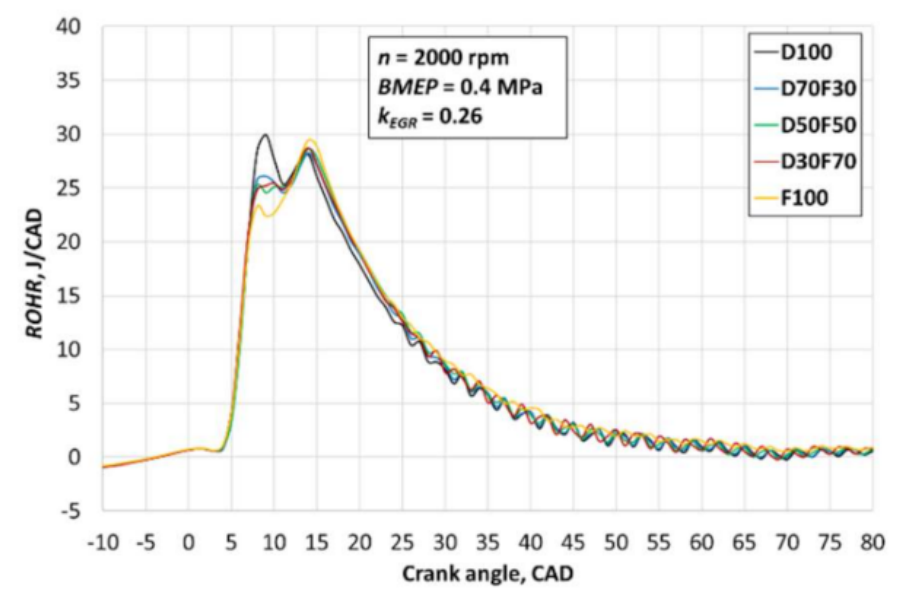

(b)

Figure 2. The in-cylinder rate of heat release depending on fuel composition with (a) exhaust gas recirculation (EGR) off and (b) EGR on.

Chicken fat injected in the cylinder did not evaporate easily, and the fuel started burning later compared with diesel due to a higher molecular weight and the tension film strength, which was also confirmed by $[39,40]$. More time was needed for the chicken fat droplets to evaporate and burn. Thus, the peak ROHR was reached at a later combustion phase. A lower ROHR reduces the intensity of thermal $\mathrm{NO}_{\mathrm{x}}$ formation in the premixed combustion phase, while a later combustion improves soot oxidation, but has a negative impact on engine energy efficiency [41].

The ROHR and rise in temperature trends were similar. The maximum rise in temperature value was reached using conventional diesel (EGR Off $\sim 57^{\circ} \mathrm{K} / \mathrm{CAD}$, EGR On $\sim 47^{\circ} \mathrm{K} / \mathrm{CAD}$ (decreased by $\sim 18 \%$ ) at $9 \mathrm{CAD}$ ATDC) (Figure 3). The maximum temperature rises of the D70F30 fuel mixture declined by $\sim 9 \%$ with EGR off and $\sim 12 \%$ with EGR on, in D50F50 by $\sim 15 \%$ and $\sim 14 \%$, respectively, in D30F70 by $\sim 21 \%$ and $\sim 17 \%$, respectively, and in F100 by $\sim 28 \%$ and $\sim 20 \%$, respectively. It was observed that when increasing the chicken fat concentration in fuel, the rise in temperature decreases in the premix phase and increases in the diffusion phase, which confirms the fact that combustion starts at a later stage and lasts longer. 


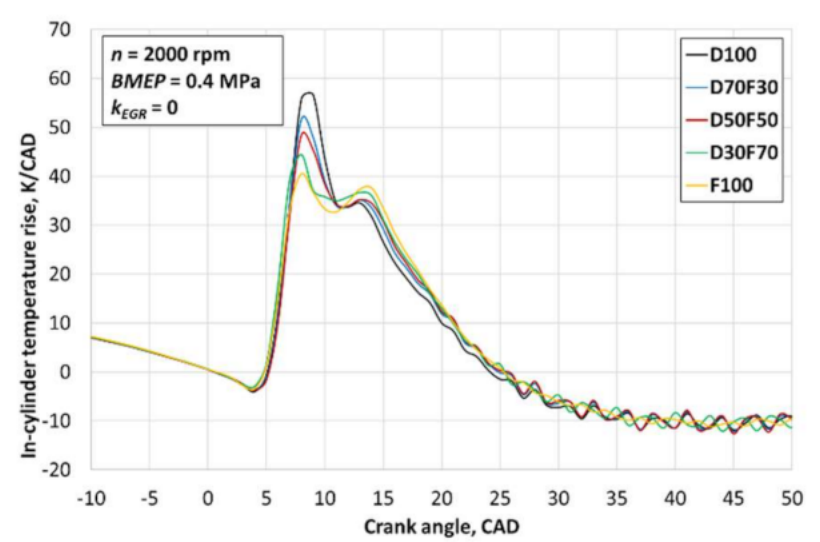

(a)

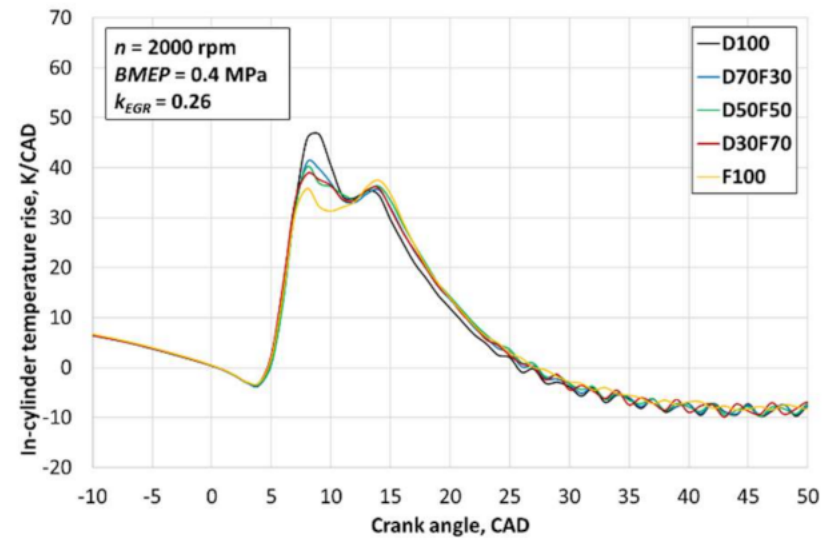

(b)

Figure 3. The in-cylinder rise in temperature, depending on fuel composition when (a) EGR is off and (b) EGR is on.

The in-cylinder temperature graph (Figure 4) also confirms the fact that increasing the chicken fat concentration led to a longer combustion process. It was observed that, having increased the chicken fat concentration in the fuel to $100 \%$, the in-cylinder temperature increased during the diffusion combustion phase from $1420 \mathrm{~K}$ to $1438 \mathrm{~K}$ with EGR off and from $1367 \mathrm{~K}$ to $1384 \mathrm{~K}$ with EGR on. This improved soot combustion, but more energy was evolved with exhaust gas. Gas of a higher temperature stayed in the cylinder, increasing the turbocharger pressure; therefore, the temperature at the end of the compression stroke was higher. This improved the ignition of the fuels that contained chicken fat additive.

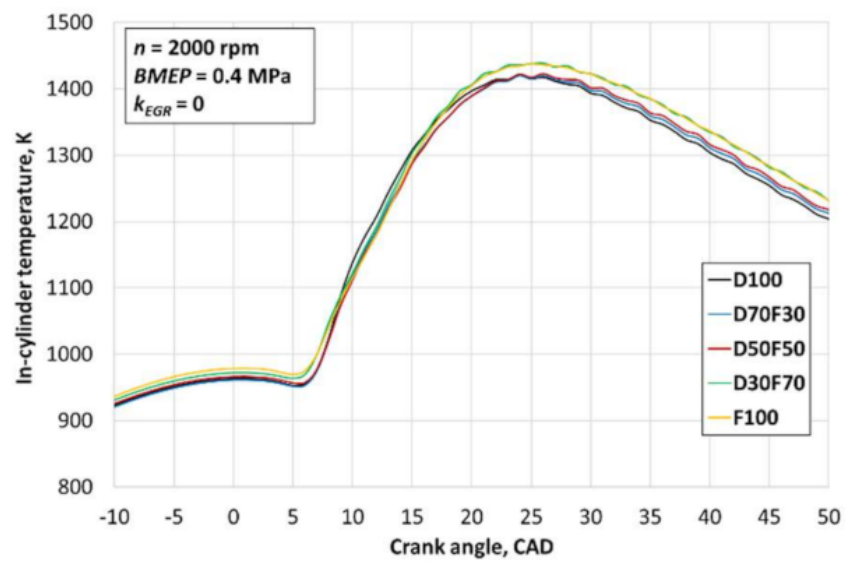

(a)

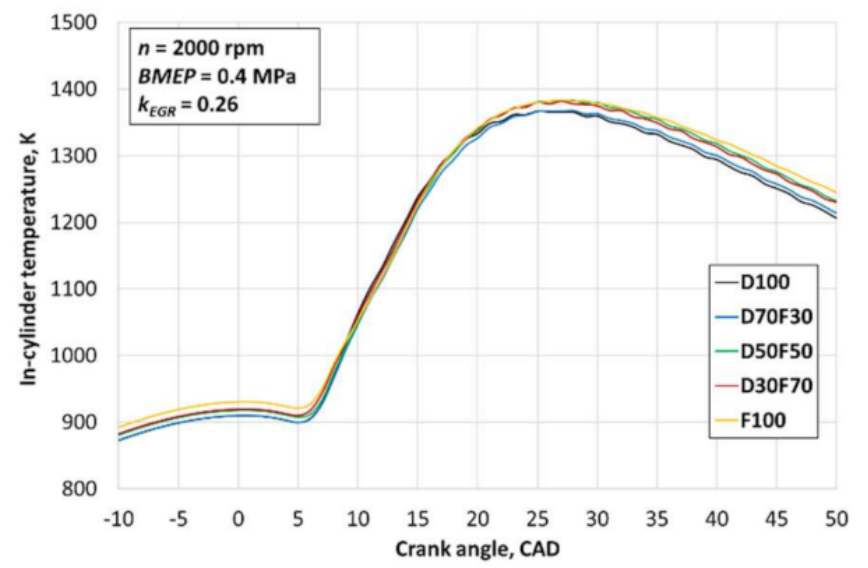

(b)

Figure 4. In-cylinder temperature, depending on fuel composition with (a) EGR off and (b) EGR on.

The highest pressure rise in the premix combustion phase was achieved using pure diesel ( 0.12 MPa/CAD with EGR off and $\sim 0.08 \mathrm{MPa} / \mathrm{CAD}$ with EGR on) (Figure 5). For D70F30, the pressure rise in the premix phase decreased $~ 17 \%$ with EGR off and $\sim 27 \%$ with EGR on, declining $\sim 30 \%$ and $\sim 35 \%$ for D50F50, $\sim 46 \%$ and $\sim 43 \%$ for D30F70 and $\sim 62 \%$ and $\sim 60 \%$ for F100, respectively. With EGR off and on, the maximum temperature rise was achieved at 8 CAD ATDC for all fuel mixtures. When increasing the chicken fat concentration in the fuels, the pressure rise declined in the premix phase and moving to the diffusion phase, which reduced the load on the engine parts and the evolved noise. 


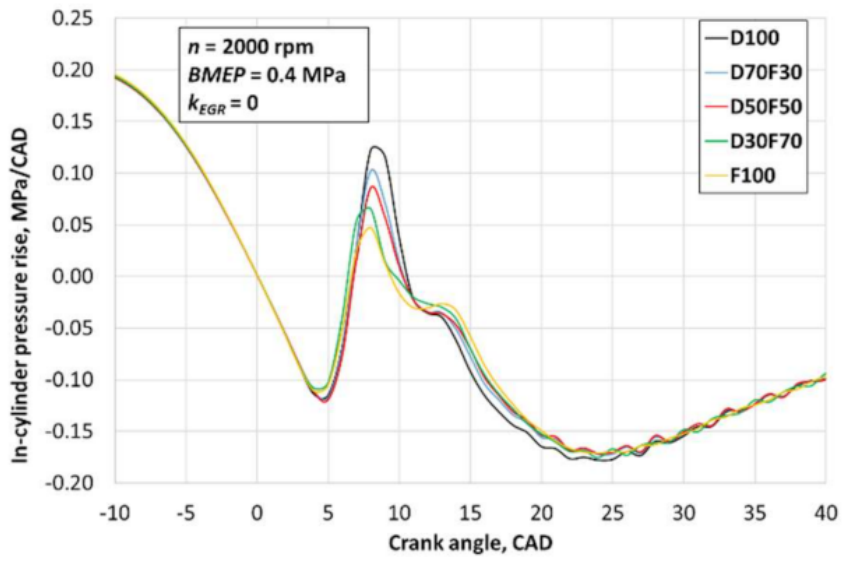

(a)

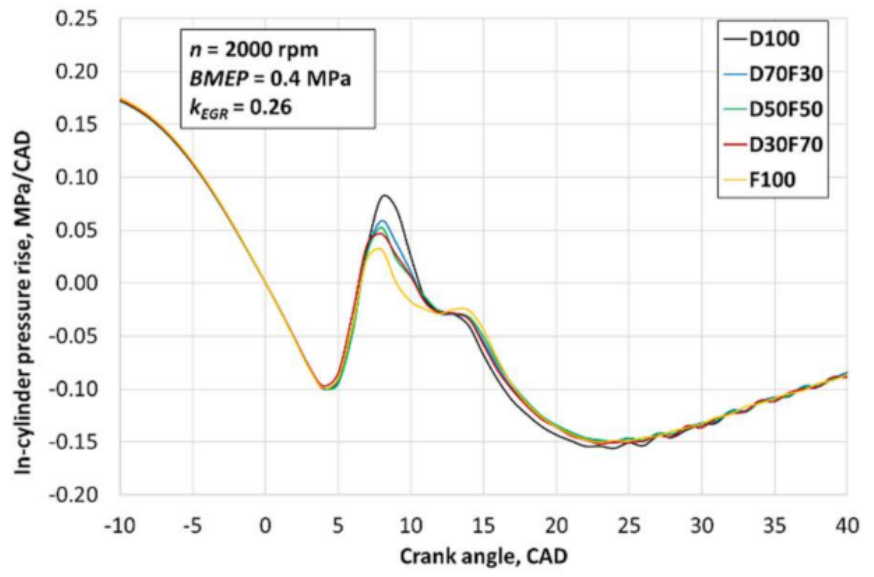

(b)

Figure 5. Pressure rise in-cylinder depending on the fuel composition with (a) EGR off and (b) EGR on.

When EGR was off and the engine ran on conventional diesel, the maximum combustion pressure in the cylinder was $\sim 6.14 \mathrm{MPa}$ and, when EGR was on, it was $\sim 5.5 \mathrm{MPa}$ ( $10 \%$ lower) (Figure 6$)$. When using pure chicken fat and its mixtures with diesel, the maximum combustion pressure declined to $\sim 6.0 \mathrm{MPa}$ and $\sim 5.4 \mathrm{MPa}$, respectively, even though the pressure of the end of compression increased. It was observed that when using diesel and its mixtures with chicken fat, the maximum combustion pressure was reached at 11 CAD ATDC, and when using chicken fat, it was reached 2 CAD earlier. This was due to a later heat release, where the piston came down and the pressure did not rise.

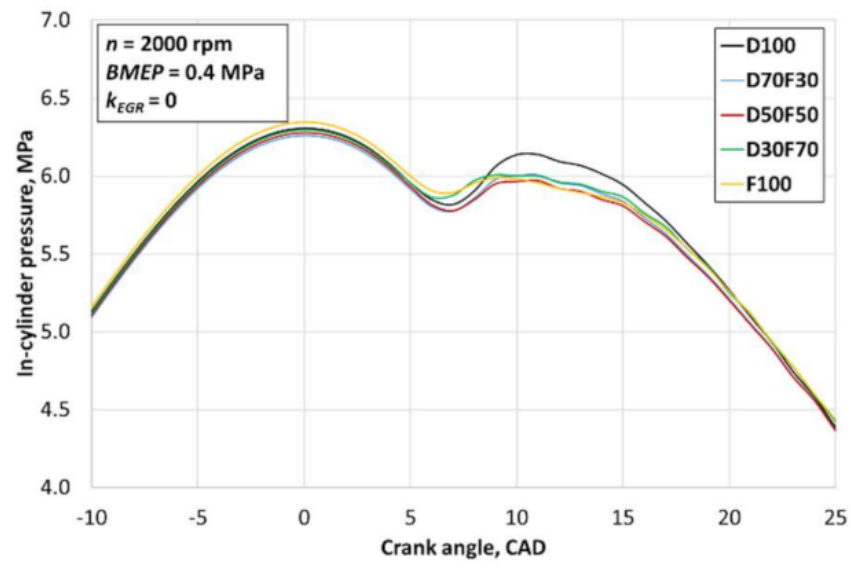

(a)

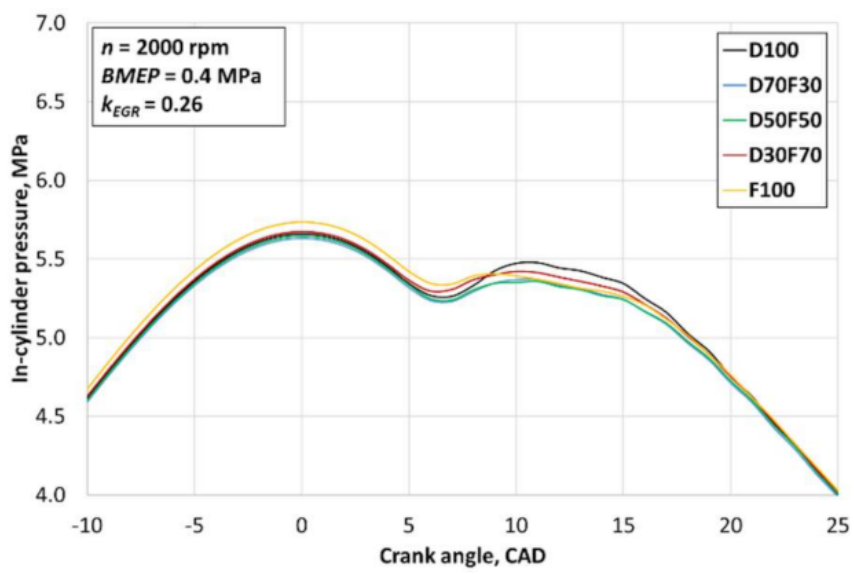

(b)

Figure 6. In-cylinder pressure depending on the fuel composition with (a) EGR off and (b) EGR on.

The exhaust flue temperature (Figure 7) and turbocharger pressure (Figure 8) measured during the experimental research confirmed the results of the numerical analysis of the combustion process. The exhaust temperature was observed to have a tendency to increase (1-2\%) both with EGR off and EGR on for all engine loads (BMEP $=0.3 \mathrm{MPa}$, $0.4 \mathrm{MPa}$ and $0.6 \mathrm{MPa}$ ) when increasing the chicken fat concentration in the fuel from $50 \%$ to $100 \%$. The flue gas temperature graph correlates with $\sim 1 \%$ turbocharger pressure. A higher exhaust energy volume was due to a later combustion of the chicken fat. 


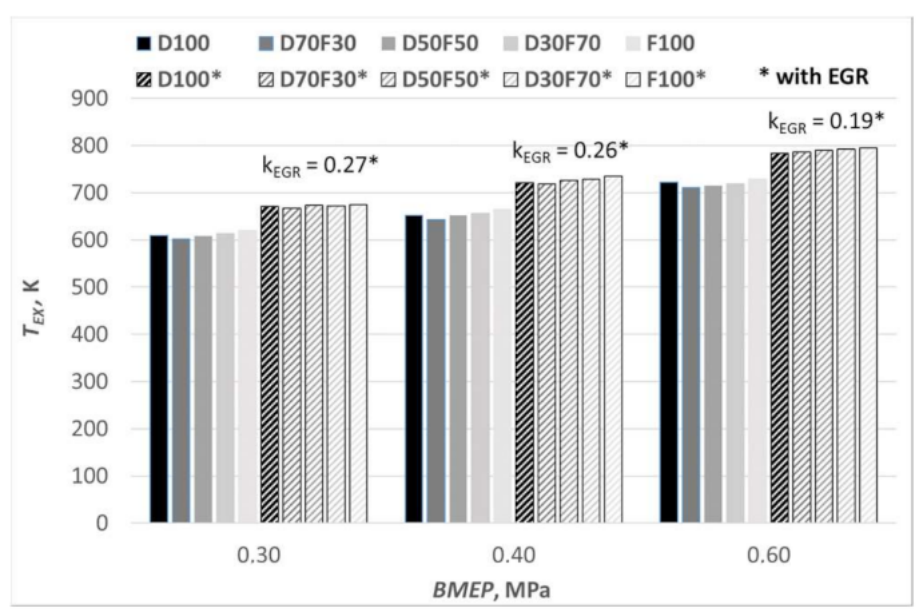

Figure 7. Dependence of exhaust temperature on fuel composition and engine load.

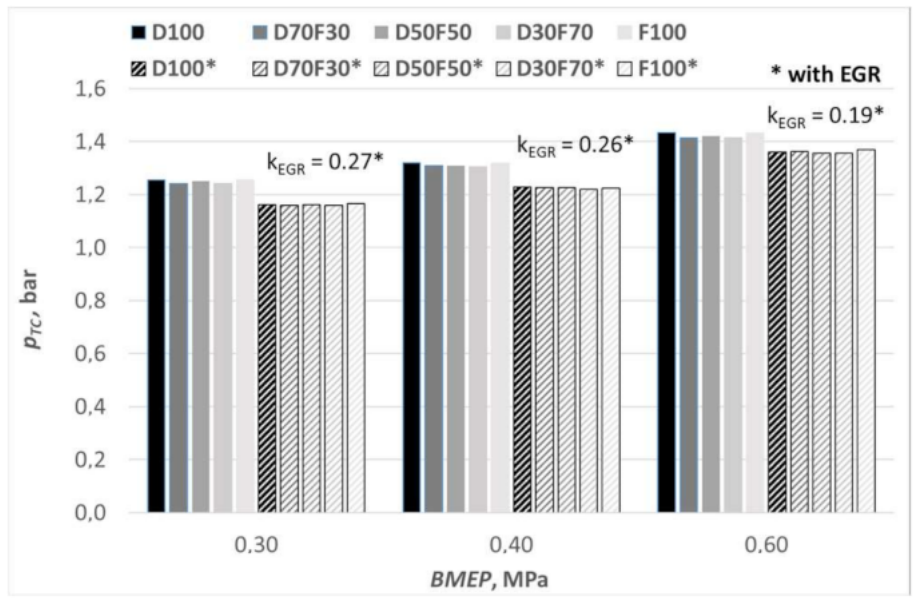

Figure 8. Dependence of turbocharger pressure on fuel composition and engine load.

A small decline in the exhaust gas temperature and the turbocharger pressure using $30 \%$ chicken fat both with EGR off and EGR on can be explained by the ROHR typical of this particular fuel mixture. The heat release of D70F30 fuel in the diffusion phase was found to be most similar to conventional diesel, and the combustion duration of this fuel mixture was slightly shorter compared with diesel, resulting in lower exhaust energy (exhaust temperature and flow). This was also confirmed by the BTE of the engine (Figure 12), where the thermal efficiencies of D70F30 and the conventional diesel were also similar. The assessment of the energy efficiency of the engine allowed for stating that the D70F30 fuel mixture energy output to the exhaust and cooling system was similar to that of pure diesel.

\subsection{Energy Indicators}

The analysis of the brake specific fuel mass consumption (BSFC_m $)$ in the experimental research revealed that, when increasing the chicken fat concentration to $100 \%$, the specific fuel mass consumption increased by $\sim 16.3 \%$ at different loads when EGR was off and by $17-19 \%$ when EGR was on (Figure 9). The results of the fuel tests revealed that the lower heating value (LHV) of F100 was $~ 11.5 \%$ lower compared with the D100 (Table 2). This means that when increasing the chicken fat concentration in the fuel, the BSFC_m increased not only due to the decreased LHV, but also due to a worse thermal efficiency in the combustion process, which became even worse when EGR was on. 


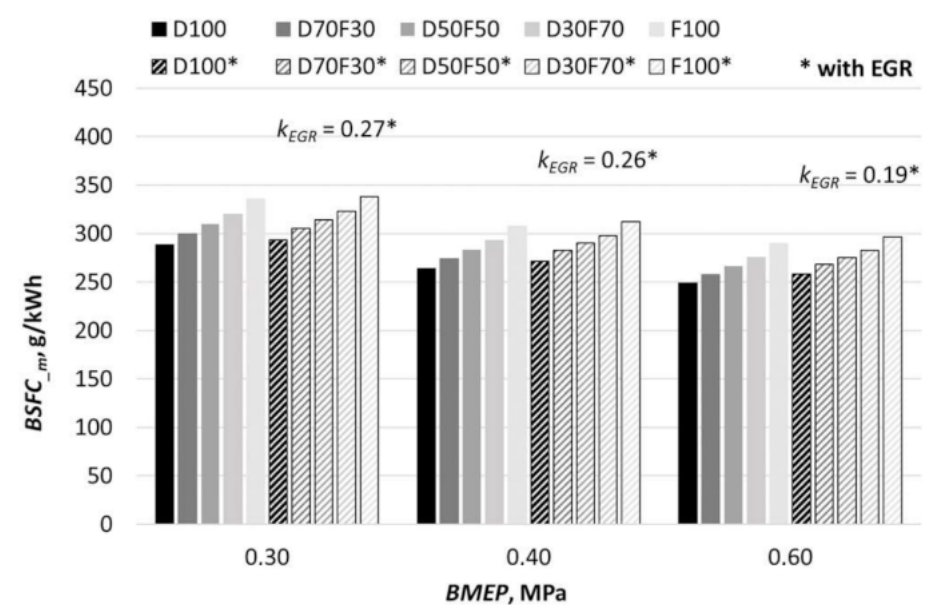

Figure 9. Dependence of brake specific fuel mass consumption on fuel composition and the engine load.

The brake specific fuel volume consumption (BSFC_V) was measured at $40{ }^{\circ} \mathrm{C}$. Under these conditions, the density of the chicken fat was $\sim 7.4 \%$ higher than the density of conventional diesel (Table 2). Therefore, the impact of chicken fat on the growth of the BSFC_V was lower compared with the growth of BSFC_m with an increasing chicken fat concentration. However, for F100, the BSFC_V remained $~ 8.3 \%$ higher than the D100 consumption with EGR being on and 9.0-11.0\% higher with EGR off (Figure 10).

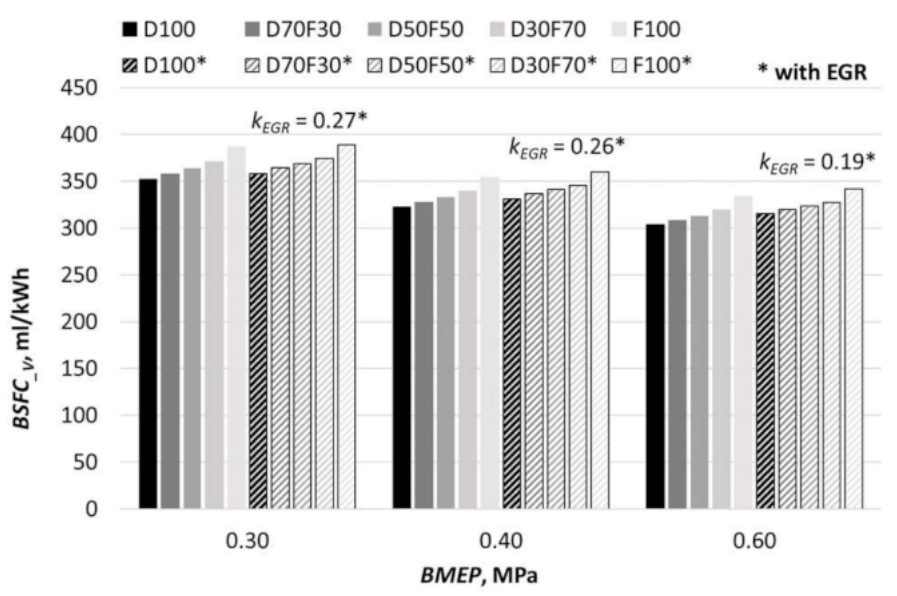

Figure 10. Dependence of brake specific fuel volume on fuel composition and the engine load.

Both the course of the combustion process and the degree of combustion (oxidation) of the fuel also had a significant impact on the engine's brake specific energy consumption (BSEC). The experimental research revealed that, having replaced the D100 with D70F30, the BSEC remained unchanged (Figure 11). An increase in the chicken fat concentration to $50 \%$ increased the BSEC by $0.8 \%$, and it increased by $1.6 \%$ for D30F70. For F100, the increase in BSEC was even higher, being $3.0 \%$ greater compared with the D100 with the engine running on different loads when EGR was off. This was due to the lower ROHR of F100 fuel in the premixed combustion phase, when a more intense combustion was postponed to a later phase. When the content of oxygen involved in combustion decreases with EGR being on, the temperature drops, also resulting in lower temperatures of fuel oxidation and, in the D100, the BSEC increased by $1.7-3.5 \%$ under different loads. When EGR was on, a gradual increase in the chicken fat concentration to $30 \%$ increased the BSEC by $2.1-3.9 \%$, whereas for D50F50 it increased by $2.3-4.0 \%$ and for D30F70 it increased by $2.6-4.2 \%$. When using F100, the increase in the BSEC was higher and, compared with the D100, increased by $3.7-5.5 \%$ at different loads. 


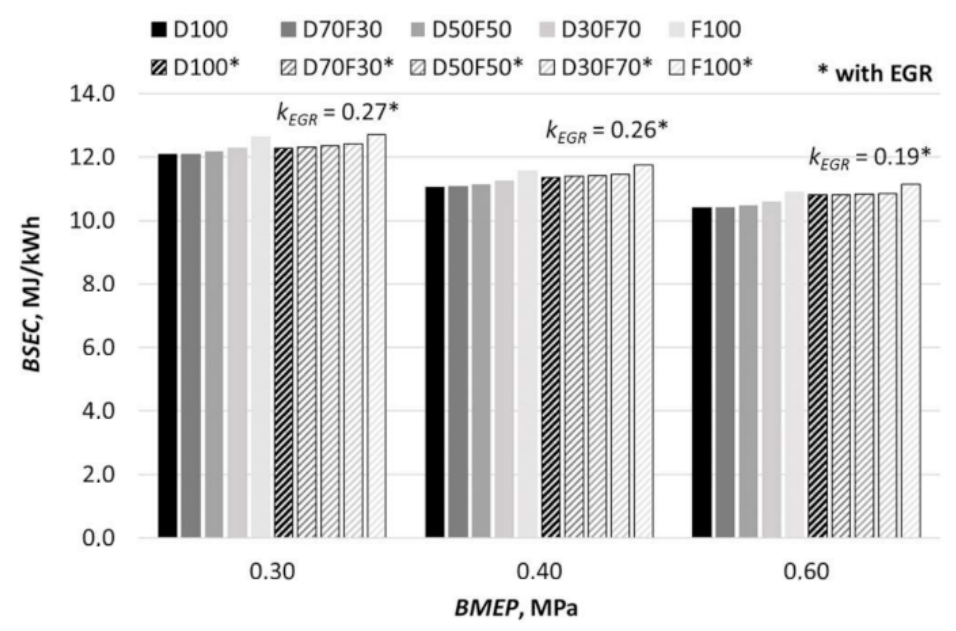

Figure 11. Dependence of brake specific energy consumption on fuel composition and the engine load.

With the increasing brake specific energy consumption of the engine, the brake thermal efficiency (BTE) decreased. At various loads and when EGR was off, the same BTE was achieved when comparing the D100 and D70F30 fuels (Figure 12), which means that the $30 \%$ chicken fat additive did not have a significant impact on the energy efficiency of the combustion process. The BTE reduced by $0.7-0.8 \%$ for the $50 \%$ chicken fat fuel, $1.5-1.6 \%$ for the $70 \%$ chicken fat fuel and $2.8-2.9 \%$ for the $100 \%$ chicken fat fuel when EGR was off. When increasing the chicken fat concentration, more heat was released to the cooling system due to a longer combustion process, and the exhaust temperature increased. When emitting more energy into the environment, the thermal efficiency of the engine decreased. Compared with EGR being off, when EGR was on, the BTE decreased by $1.7-3.4 \%$ in the D100 because gas recirculation also reduced the combustion intensity in the premix phase (Figure $3 b$ ) and increased the combustion duration. In addition, a lower oxygen content was involved in the combustion, which resulted in a worse combustion quality, increasing the smoke and decreasing the thermal efficiency. When increasing the chicken fat concentration with EGR being on, the smoke decreased, but this was due to an even longer combustion process, which further reduced the BTE. Having increased the chicken fat concentration to $100 \%$ when EGR was on, the BTE decreased by $3.5-5.1 \%$ at various loads compared with the D100 and EGR being off.

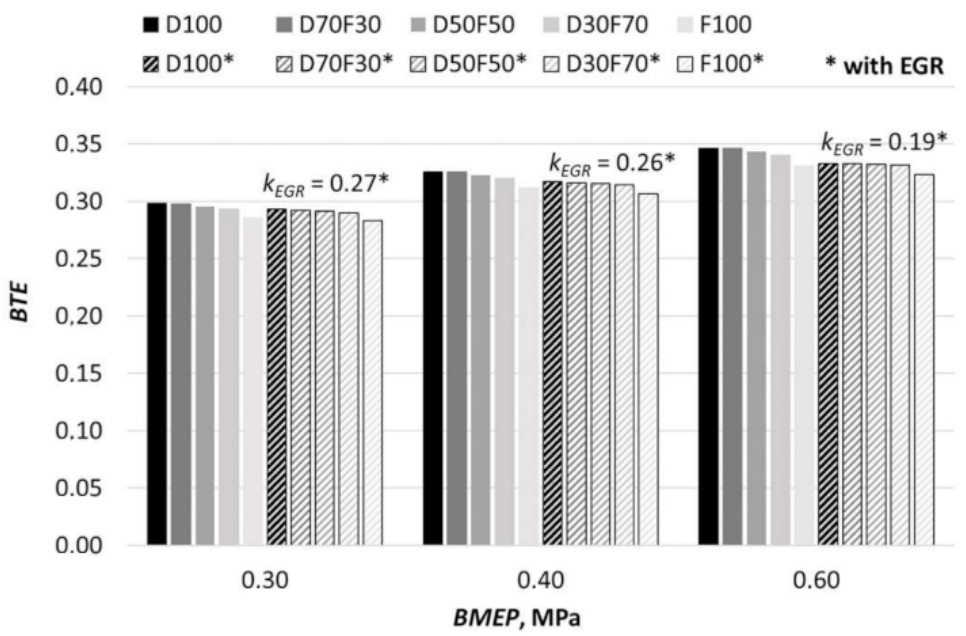

Figure 12. Dependence of brake thermal efficiency on fuel composition and the engine load. 


\subsection{Environmental Indicators}

The carbon dioxide $\left(\mathrm{CO}_{2}\right)$ contained in the exhaust gas was a product of full combustion which formed when there was enough oxygen for a full combustion process to take place. On the other hand, the $\mathrm{CO}_{2}$ content increased with the increasing carbon content in the fuel molecule. Research of the chemical and physical properties of the fuel revealed that the carbon/hydrogen mass ratio in the D100 was 6.31, and it was 6.48 (2.7\% higher) in the F100 (Table 2). The analysis of the key differences between diesel and chicken fat molecules distinguished a higher carbon content in the diesel molecules and the replacement of alkane chains - which form diesel hydrocarbons, for the most part-with chains of fatty acids that contain the isomeric branches in chicken fat. This accordingly affected $\mathrm{CO}_{2}$ formation processes, where oxidation kinetics became faster with the formation of peroxide foci, and larger amounts of full combustion products, such as $\mathrm{CO}_{2}$, formed during combustion [42]. This trend is also illustrated in the graph (in Figure 13), which shows that when increasing the chicken fat concentration in the mixtures at all engine loads, the $\mathrm{CO}_{2}$ emissions tended to increase when the fat concentration exceeded $30 \%$. Having replaced the diesel with pure fat, the $\mathrm{CO}_{2}$ emissions increased by $4-5 \%$ when EGR was off. In addition to the above-listed reasons, the increase in $\mathrm{CO}_{2}$ emissions was also affected by the rising fuel consumption (chicken fat consumes $\sim 16.3 \%$ more when EGR is off and consumes $\sim 18 \%$ more when EGR is on (Figure 9)). Fuel consumption increased as EGR reduced the BTE of the engine (Figure 12). With EGR on and the engine running on diesel, the F100 fuel's $\mathrm{CO}_{2}$ emissions, compared with the D100, increased by $8-9 \%$ and by $11 \%$ and $12-15 \%$, reaching $1100 \mathrm{~g} / \mathrm{kWh}$ when increasing the fat concentration to $100 \%$ at a low engine load $(\mathrm{BMEP}=0.3 \mathrm{MPa})$. Increasing the engine load to medium $(\mathrm{BMEP}=0.6)$ decreased the BSFC (Figure 9) and reduced the $\mathrm{CO}_{2}$ emissions. However, chicken fat can be considered a renewable fuel, and thus the $\mathrm{CO}_{2}$ emissions decline when assessing the life cycle of fuel.

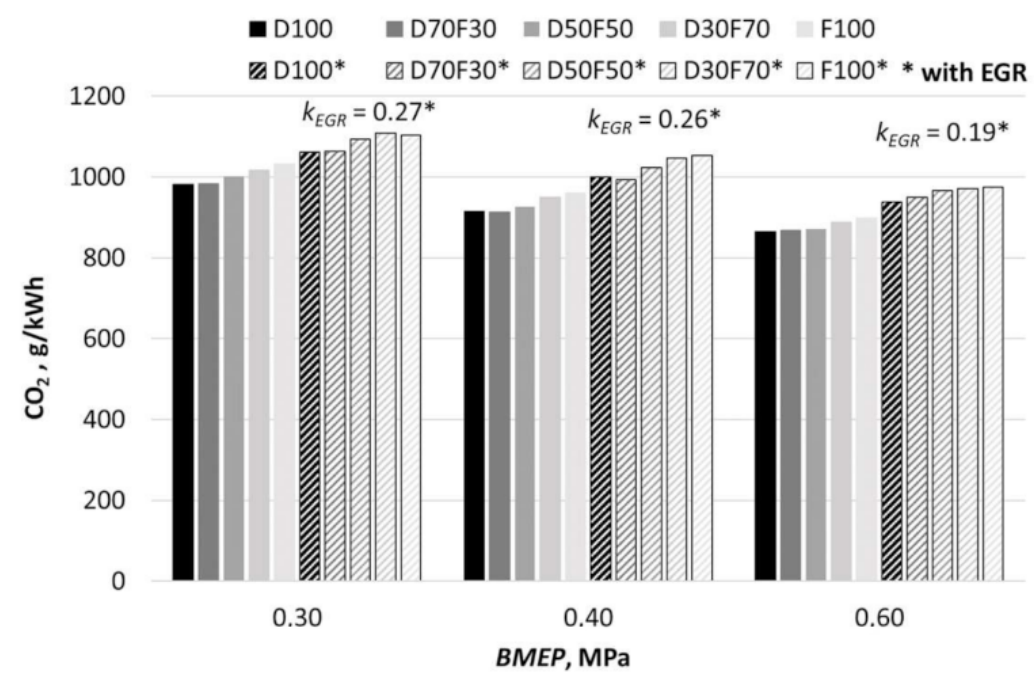

Figure 13. Dependence of $\mathrm{CO}_{2}$ emissions on fuel composition and engine load.

Increasing the concentration of the fat in the fuel mixture increased its viscosity and injection quality, while a larger droplet size of the fuel mixture in the cylinder had an adverse impact on the combustion process, as it failed to evaporate, mix with compressed air and burn, resulting in an incomplete combustion product: carbon monoxide (CO). Given the ROHR (Figure 2), we see that increasing the concentration of the chicken fat in diesel decreased the heat release and combustion temperature in the premixed combustion phase, which resulted in a worse combustion process and an increase in $\mathrm{CO}$ emissions (Figure 14). However, the $\mathrm{CO}$ emissions were not high in the diesel engine due to excess air, and it ranged from $0.75 \mathrm{~g} / \mathrm{kWh}$ to $3.5 \mathrm{~g} / \mathrm{kWh}$ in the experimental research. When increasing the concentration of chicken fat in the fuel to $100 \%$, the CO emissions increased by up to $30-80 \%$ under various loads with EGR off. With EGR on, the combustion process was even 
worse, resulting in higher $\mathrm{CO}$ emissions due to the reduced oxygen concentration in the cylinder (Figure 15) and further reduced combustion temperature (Figure 4). Compared with pure diesel, when EGR was off, the CO emissions increased to $57-88 \%$ when using pure fat with EGR off. This is in line with research on waste vegetable oil and waste animal oil-based biodiesel [25]. CO-specific emissions reduced due to a decrease in the BSFC, increasing the engine load from low $(\mathrm{BMEP}=0.3 \mathrm{MPa})$ to medium $(\mathrm{BMEP}=0.6 \mathrm{MPa})$, and the combustion temperature increased.

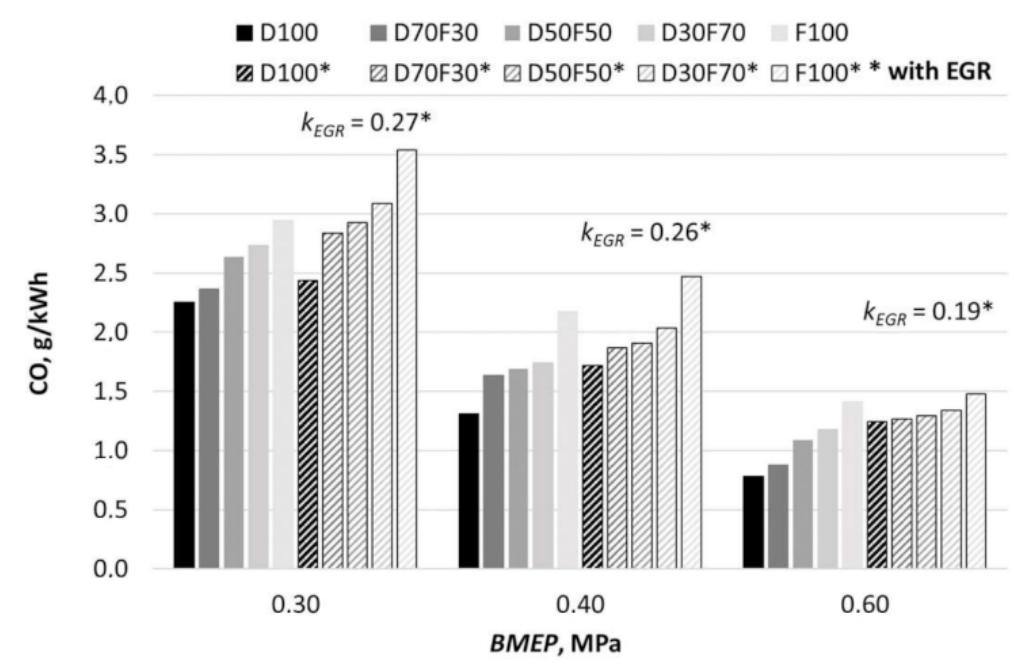

Figure 14. Dependence of CO emissions on fuel composition and engine load.

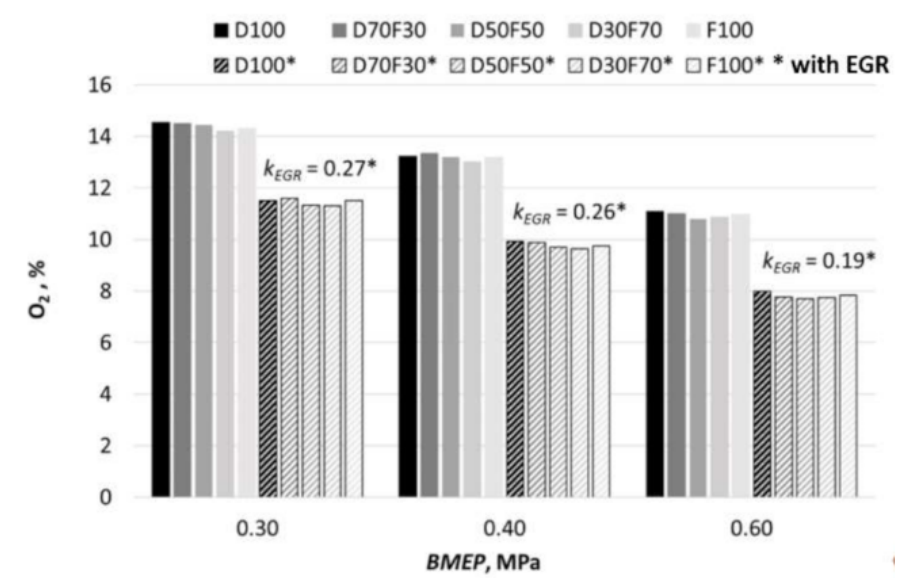

Figure 15. Dependence of the $\mathrm{O}_{2}$ concentration on fuel composition and the engine load.

The assessment of the fuel composition (Table 2) allowed for determining that the stoichiometric air/fuel ratio $(\mathrm{kg} / \mathrm{kg})$ for the D100 fuel was $14.75 \mathrm{~kg}$ and $12.60 \mathrm{~kg}$ for the F100 (14.5\% less). The lower required air mass was due to the oxygen $\left(\mathrm{O}_{2}\right)$ contained in the fuel. Increasing the engine load to medium $(\mathrm{BMEP}=0.6 \mathrm{MPa})$ increased the hourly fuel consumption but decreased the BSFC (Figure 9) as the BTE increased (Figure 12). However, the BSFC increased at different engine loads, and having replaced the D100 with F100, it increased by $\sim 16$ when EGR was off and $\sim 18 \%$ when EGR was on. This is why the $\mathrm{O}_{2}$ concentration in the exhaust gas decreased somewhat by $1.7-2.5 \%$ with EGR off and when the fuel contained $50-70 \%$ chicken fat (Figure 15). With EGR on, the $\mathrm{O}_{2}$ concentration in the exhaust gas decreased by $21-28 \%$ at different loads due to a lower intake of air mass. When using chicken fat, the $\mathrm{O}_{2}$ concentration declined by an additional 1.4-2.5\%. However, the $\mathrm{O}_{2}$ concentration was observed to slightly increase when the chicken fat concentration was $100 \%$. This was due to the exhaust energy being intensified by a longer combustion process, 
which increased the turbocharger pressure (Figure 8). The engine volumetric efficiency depended on the turbocharger pressure.

A higher fuel $\mathrm{C} / \mathrm{H}$ ratio, as well as the decreasing $\mathrm{O}_{2}$ concentration in the exhaust gases, suggests that an increase in the chicken fat concentration in the fuel increases the opacity of exhaust gases. However, the experimental research results were the opposite; at different engine loads and with EGR being off, increasing the chicken fat concentration from $0 \%$ to $100 \%$ led to a gradual decline in the smoke by $57-70 \%$ (Figure 16 ).

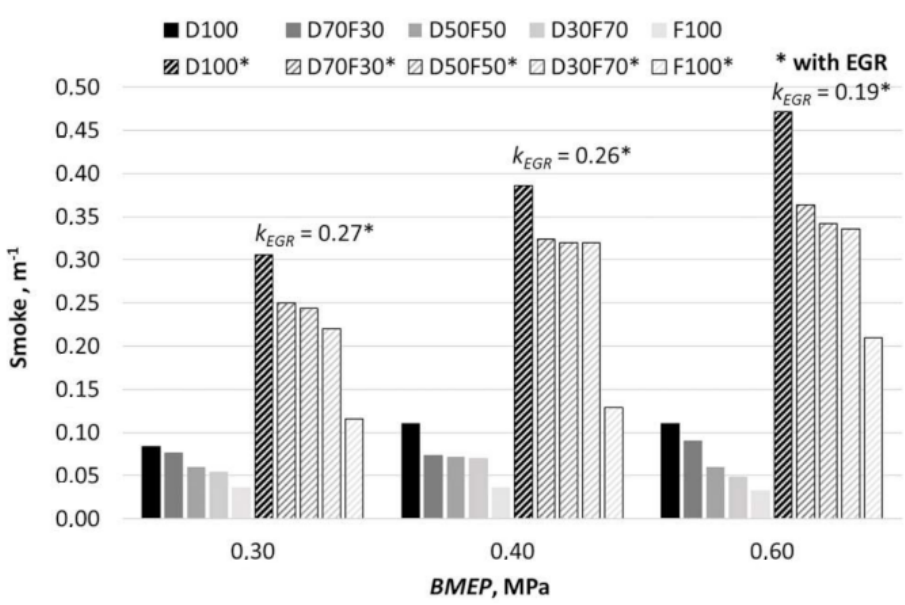

Figure 16. Dependence of the smoke on fuel composition and the engine load.

With EGR on, a lower excess air and lower combustion temperature resulted in an increase in the smoke opacity of the D100 fuel by 2.5-3.3 times compared with when EGR was off. When using the D70F30 fuel mixture, the smoke decreased by $16-23 \%$, and when using the F100, the smoke decreased by as much as 2.3-3.0 times compared with the D100 when EGR was on. Increasing the concentration of the chicken fat decreased the smoke due to a later combustion process. Soot burns better in the diffusion phase with a more intense ROHR and higher combustion temperature compared with D100. Oxygen contained in the chicken fat also contributes to the better combustion of soot.

The compression ignition engine operated in the presence of excess air and, therefore, the concentration of unburnt hydrocarbons (HCs) in the exhaust gas was low. With the engine running at different loads, increasing the chicken fat concentration in the fuel to $50 \%$ led to a slight downward trend in HC emissions, which decreased to $6 \%$ when EGR was off (Figure 17). However, when increasing the chicken fat concentration above 50\%, the $\mathrm{HC}$ emissions started increasing again, which likely was due to the deteriorating quality of the injection due to the increasing fuel viscosity. The chicken fat also had a similar impact on HC emissions with EGR being on.

The combustion temperature and oxygen that was not used during combustion had a major impact on the nitrogen oxide $\left(\mathrm{NO}_{\mathrm{x}}\right)$ emissions. The experimental research revealed that when increasing the concentration of the chicken fat in the fuel, the $\mathrm{NO}_{x}$ emissions gradually decreased in the engine throughout the entire research range. Having replaced the D100 with F100, with EGR off, the $\mathrm{NO}_{\mathrm{x}}$ emissions were reduced by $13-22 \%$ at various loads (Figure 18).

This can be explained by a lower ROHR intensity, a lower rise in temperature and the cylinder temperature in the premix phase (Figure 2a). In their experimental research on the use of vegetable oils and animal fats in compression ignition engines, Simsek and Uslu [25] observed the opposite change and stated that more nitrogen atoms reacted with oxygen, leading to higher $\mathrm{NO}_{\mathrm{x}}$ emissions due to a high oxygen content. The mixtures used in this experimental research had higher contents of aromatic substances, higher oxygen contents and higher densities than that of diesel. As a result, the $\mathrm{NO}_{\mathrm{x}}$ emissions increased when using chicken fat. However, the results of the experimental research conducted by Erdogan et al. [43] did not demonstrate such an increase in the concentration of nitrogen 
oxides. The concentrations of nitrogen oxides remained essentially the same with different fuel mixtures (ultra-low sulphur diesel, 50\% chicken fat and 100\% chicken fat) and at different engine loads.

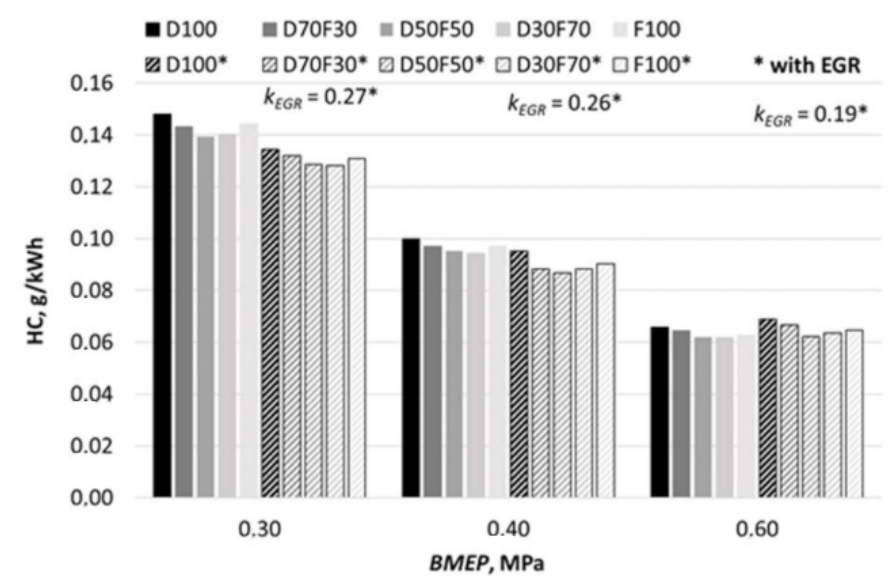

Figure 17. Dependence of hydrocarbon (HC) emissions on fuel composition and the engine load.

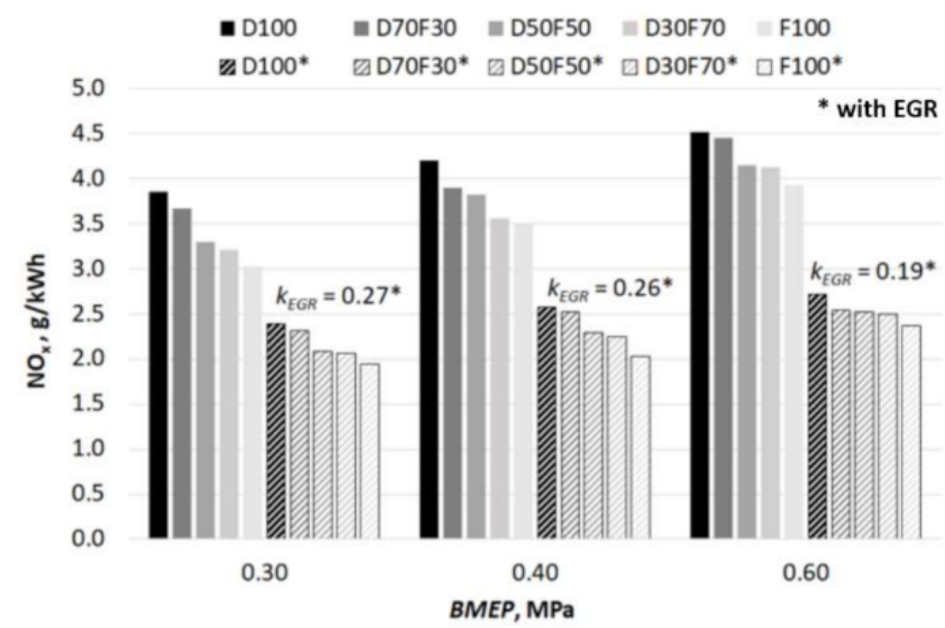

Figure 18. Dependence of nitrogen oxide $\left(\mathrm{NO}_{\mathrm{x}}\right)$ emissions on fuel composition and the engine load.

The experimental research revealed that with an engine running on D100 fuel at various loads, EGR reduced $\mathrm{NO}_{x}$ emissions by $38-40 \%$ (Figure 18) because the combustion temperature (Figure 4 ) and the concentration of free oxygen (Figure 15) decreased. Having increased the chicken fat concentration to $100 \%, \mathrm{NO}_{\mathrm{x}}$ emissions further decreased by $\sim 10 \%$ when EGR was on, compared with the D100 fuel, where its concentration decreased by $48-52 \%$ when EGR was off. The impact of chicken fat on reducing $\mathrm{NO}_{\mathrm{x}}$ emissions with EGR on was lower because the ROHR intensity in the F100 fuel decreased less compared with the D100 in the premix combustion phase (Figure 2b). However, the combined impact of the use of EGR and chicken fat on reducing $\mathrm{NO}_{\mathrm{x}}$ emissions was significant.

\section{Conclusions}

The following conclusions were made, having conducted the experimental research of a compression ignition engine running on pure conventional diesel (D100) fuel and pure chicken fat (F100), as well as mixtures of these fuels (D70F30, D50F50 and D30F70) at various engine loads with EGR on and off, as well as numerical analysis of the combustion process:

1. When using fuel which contains chicken fat, the fuel was heated to $\sim 50{ }^{\circ} \mathrm{C}$ in order to reduce the high viscosity and fuel filter plugging. The comparison of the F100 and D100 fuels revealed that the chicken fat lubricity properties were no worse, the 
density was $\sim 7.4 \%$ higher, the LHV was $\sim 11.5 \%$ lower and the $\mathrm{C} / \mathrm{H}$ ratio was $\sim 2.7 \%$ higher, while oxygen accounted for $\sim 11 \%$ of the chicken fat mass;

2. When increasing the concentration of the chicken fat in the fuel mixtures, the intensity of the fuel injection, evaporation and combustion changed due to the changed fuel properties. Having replaced the D100 with F100 fuel, the start of ignition timing was determined to change slightly, but the maximum ROHR decreased by $\sim 27 \%$ in the premixed combustion phase when EGR was on and by $\sim 22 \%$ when EGR was off, and combustion in the diffusion phase was more intense. The turbocharger boost pressure, which depends on the kinetic energy of the exhaust gas, increases, which in turn increases the volumetric efficiency of the engine. The specific fuel mass consumption (BSFC_m) of the F100 fuel increased by 16\% when EGR was off and by $\sim 18 \%$ when EGR was on, due to a lower chicken fat LHV and a lower combustion thermal efficiency. It was found that, with the engine running at different loads when EGR was off, an increase of the chicken fat concentration to $30 \%$ left the engine's BTE unchanged, but increasing the fat concentration to $100 \%$ decreased the efficiency by $2.8-2.9 \%$ due to a longer combustion process. When EGR was on, the combustion process was even longer, and the engine's BTE decreased by $3.5-5.1 \%$ when using F100 duel, compared with D100, when EGR was off;

3. An increase in the engine's $\mathrm{CO}_{2}$ emissions when increasing the concentration of the chicken fat was due to a higher $\mathrm{C} / \mathrm{H}$ ratio of the $\mathrm{F} 100$ fuel, increasing fuel consumption and the specifics of combustion of the chicken fat containing $\mathrm{O}_{2}$. However, the fact that the F100 fuel is a renewable fuel allows for stating that the $\mathrm{CO}_{2}$ emissions of this fuel during the life cycle are much lower compared with D100;

4. When increasing the chicken fat concentration, $\mathrm{CO}$ emissions also increased as the $\mathrm{C} / \mathrm{H}$ ratio increased and larger droplets of higher fuel density burned harder. EGR further increased $\mathrm{CO}$ emissions as the combustion temperature and the amount of oxygen involved in oxidation decreased. HC emissions decreased slightly when increasing the chicken fat concentration to $50 \%$, but when the fat concentration increased to $100 \%$, the $\mathrm{HC}$ emissions increased due to worse combustion;

5. Although a higher $\mathrm{C} / \mathrm{H}$ ratio in the $\mathrm{F} 100$ fuel and the increasing fuel consumption when increasing the chicken fat concentration should theoretically increase the amount of smoke, the smoke decreased by $57-70 \%$ when EGR was off. This was due to a slower combustion in the premixed combustion phase, more intense combustion in the diffusion phase and the oxygen contained in the fuel;

6. Decreasing the chicken fat $\mathrm{ROHR}$ in the premix combustion phase resulted in a lower $\mathrm{NO}_{\mathrm{x}}$ formation intensity. When EGR was off, the $100 \%$ chicken fat fuel reduced $\mathrm{NO}_{\mathrm{x}}$ emissions at various loads by $13-22 \%$, and when EGR was on, the combined effects of EGR and the chicken fat reached $48-52 \%$.

Author Contributions: Conceptualization, A.R. and J.M.; methodology, A.R., T.V. and D.K.; software, A.R. and S.S.; formal analysis, A.R. and J.M.; validation, A.R. and S.S.; writing—original draft preparation, T.V., A.R. and S.S.; writing-review and editing, J.M. and A.R.; supervision, J.M. and A.R.; project administration, A.R. and J.M. All authors have read and agreed to the published version of the manuscript.

Funding: This research received no external funding.

Institutional Review Board Statement: Not applicable.

Informed Consent Statement: Not applicable.

Data Availability Statement: The study did not report any data.

Acknowledgments: The authors thank the AVL company for the opportunity to use the engine simulation tool AVL BOOST, which was used to analyze the combustion process and present the results. A cooperation agreement has been concluded between the faculty of the Transport Engineering of Vilnius Gediminas Technical University and AVL Advanced Simulation Technologies.

Conflicts of Interest: The authors declare no conflict of interest. 


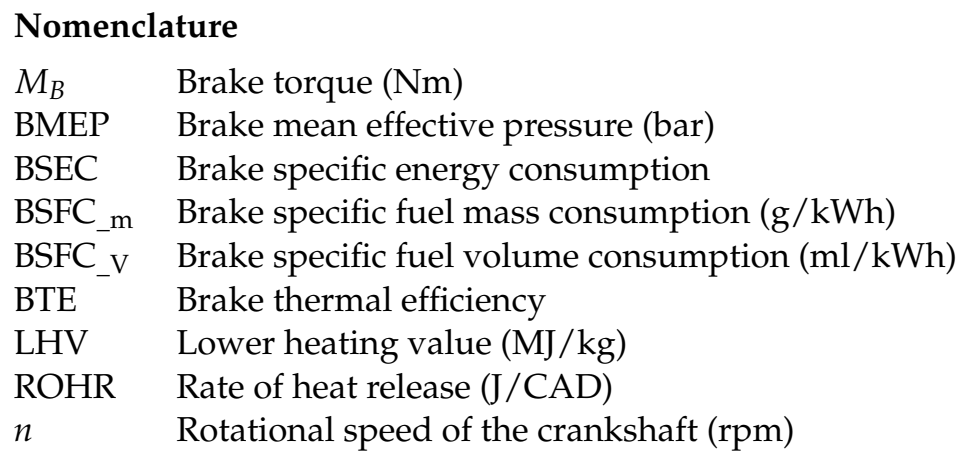

$\begin{array}{ll}\text { Abbreviations } \\ \text { ATDC } & \text { After top dead center } \\ \text { BTDC } & \text { Before top dead center } \\ \text { CAD } & \text { Crank angle degree } \\ \text { CFPP } & \text { Cold filter plugging point } \\ \text { CI } & \text { Compression ignition } \\ \text { CO } & \text { Carbon monoxide } \\ \mathrm{CO}_{2} & \text { Carbon dioxide } \\ \text { D100 } & 100 \% \text { conventional diesel fuel } \\ \text { D30F70 } & 30 \% \text { diesel, 70\% chicken fat } \\ \text { D50F50 } & 50 \% \text { diesel, 50\% chicken fat } \\ \text { D70F30 } & 70 \% \text { diesel, } 30 \% \text { chicken fat } \\ \text { ECU } & \text { Electronic control unit } \\ \text { EGR } & \text { Exhaust gas recirculation } \\ \text { F100 } & 100 \% \text { chicken fat fuel } \\ \text { HC } & \text { Hydrocarbon } \\ \text { HCCI } & \text { Homogeneous charge compression ignition } \\ \text { NO } & \text { Nitrogen oxide } \\ \mathrm{O}_{2} & \text { Oxygen } \\ \text { SOC } & \text { Start of combustion } \\ \text { SOI } & \text { Start of injection } \\ \text { TDI } & \text { Turbocharged direct injection } \\ \text { WSD } & \text { Wear scar diameter }\end{array}$

\section{References}

1. Selech, J.; Ulbrich, D.; Wlodarczyk, K.; Kowalczyk, J.; Adamkiewicz, J. The Prototype of Stream Amplifier Used in Transport of Polydisperse Medium. Procedia Eng. 2017, 192, 777-781. [CrossRef]

2. Fuc, P.; Lijewski, P.; Kurczewski, P.; Ziolkowski, A.; Dobrzynski, M. The analysis of fuel consumption and exhaust emissions from forklifts fueled by diesel fuel and liquefied petroleum gas (LPG) obtained under real driving conditions. In Proceedings of the Asme International Mechanical Engineering Congress and Exposition, Tampa, FL, USA, 3-9 November 2017.

3. Bereczky, A. The Past, Present and Future of the Training of Internal Combustion Engines at the Department of Energy Engineering of BME. In Vehicle and Automotive Engineering; Jarmai, K., Bollo, B., Eds.; Springer: Cham, Switzerland, 2017; pp. $225-234$.

4. Rimkus, A.; Matijosius, J.; Bogdevicius, M.; Bereczky, A.; Torok, A. An Investigation of the Efficiency of Using O-2 and H-2 (Hydrooxile Gas-HHO) Gas Additives in a Ci Engine Operating on Diesel Fuel and Biodiesel. Energy 2018, 152, 640-651. [CrossRef]

5. Ayhan, V.; Tunca, S. Experimental Investigation on Using Emulsified Fuels with Different Biofuel Additives in a DI Diesel Engine for Performance and Emissions. Appl. Therm. Eng. 2018, 129, 841-854. [CrossRef]

6. Kukharonak, H.; Ivashko, V.; Pukalskas, S.; Rimkus, A.; Matijošius, J. Operation of a Spark-Ignition Engine on Mixtures of Petrol and N-Butanol. Procedia Eng. 2017, 187, 588-598. [CrossRef]

7. Warguła, Ł.; Kukla, M.; Lijewski, P.; Dobrzyński, M.; Markiewicz, F. Influence of the Use of Liquefied Petroleum Gas (LPG) Systems in Woodchippers Powered by Small Engines on Exhaust Emissions and Operating Costs. Energies 2020, 13, 5773. [CrossRef]

8. Zoldy, M.; Hollo, A.; Thernesz, A. Butanol as a Diesel Extender Option for Internal Combustion Engines. In SAE 2010 World Congress \& Exhibition; SAE International: Troy, MI, USA, 12 April 2010. [CrossRef] 
9. Fuc, P.; Lijewski, P.; Sokolnicka, B.; Siedlecki, M.; Szymlet, N. Analysis of exhaust gas flow through a particulate filter in the exhaust of the spark ignition direct injection engine. In Proceedings of the Computational Technologies in Engineering (TKI'2018), Jora Wielka, Poland, 16-19 October 2018; Volume 2078.

10. Rimkus, A.; Zaglinskis, J.; Stravinskas, S.; Rapalis, P.; Matijosius, J.; Bereczky, A. Research on the Combustion, Energy and Emission Parameters of Various Concentration Blends of Hydrotreated Vegetable Oil Biofuel and Diesel Fuel in a CompressionIgnition Engine. Energies 2019, 12, 2978. [CrossRef]

11. Kilikevičienè, K.; Kačianauskas, R.; Kilikevičius, A.; Maknickas, A.; Matijošius, J.; Rimkus, A.; Vainorius, D. Experimental Investigation of Acoustic Agglomeration of Diesel Engine Exhaust Particles Using New Created Acoustic Chamber. Powder Technol. 2020, 360, 421-429. [CrossRef]

12. Rimkus, A.; Melaika, M.; Matijošius, J. Efficient and Ecological Indicators of CI Engine Fuelled with Different Diesel and LPG Mixtures. Procedia Eng. 2017, 187, 504-512. [CrossRef]

13. Alptekin, E.; Canakci, M.; Ozsezen, A.N.; Turkcan, A.; Sanli, H. Using Waste Animal Fat Based Biodiesels-Bioethanol-Diesel Fuel Blends in a DI Diesel Engine. Fuel 2015, 157, 245-254. [CrossRef]

14. Bereczky, A. Effect of The use of waste vegetable oil based biodiesel on the landscape in diesel engines. Therm. Sci. 2017, 21, 567-579. [CrossRef]

15. Zöldy, M.; Török, Á. Road Transport Liquid Fuel Today and Tomorrow: Literature Overview. Period. Polytech. Transp. Eng. 2015, 43, 172-176. [CrossRef]

16. Warguła, Ł.; Kukla, M. Determination of Maximum Torque during Carpentry Waste Comminution. Wood Res. 2020, 65, 771-784. [CrossRef]

17. Zefreh, M.M.; Hussain, B.; Sipos, T. In-Depth Analysis and Model Development of Passenger Satisfaction with Public Transportation. KSCE J. Civ. Eng. 2020, 24, 3064-3073. [CrossRef]

18. Veselik, P.; Sejkorova, M.; Nieoczym, A.; Caban, J. Outlier Identification of Concentrations of Pollutants in Environmental Data Using Modern Statistical Methods. Pol. J. Environ. Stud. 2020, 29, 853-860. [CrossRef]

19. Fuc, P.; Lijewski, P.; Ziolkowski, A.; Dobrzyński, M. Dynamic Test Bed Analysis of Gas Energy Balance for a Diesel Exhaust System Fit with a Thermoelectric Generator. J. Elec Mater. 2017, 46, 3145-3155. [CrossRef]

20. Melnikienè, R.; Baležentis, A. Agricultural and Food Sector in Lithuania 2017; Lithuanian Institute of Agrarian Economics: Vilnius, Lithuania, 2018.

21. Andrzejczak, K.; Młyńczak, M.; Selech, J. Poisson-Distributed Failures in the Predicting of the Cost of Corrective Maintenance. EiN 2018, 20, 602-609. [CrossRef]

22. Barua, P.; Hossain, N.; Chowdhury, T.; Chowdhury, H. Commercial Diesel Application Scenario and Potential of Alternative Biodiesel from Waste Chicken Skin in Bangladesh. Environ. Technol. Innov. 2020, 20, 101139. [CrossRef]

23. Keskin, A.; Şen, M.; Emiroğlu, A.O. Experimental Studies on Biodiesel Production from Leather Industry Waste Fat and Its Effect on Diesel Engine Characteristics. Fuel 2020, 276, 118000. [CrossRef]

24. Emiroğlu, A.O.; Keskin, A.; Şen, M. Experimental Investigation of the Effects of Turkey Rendering Fat Biodiesel on Combustion, Performance and Exhaust Emissions of a Diesel Engine. Fuel 2018, 216, 266-273. [CrossRef]

25. Simsek, S.; Uslu, S. Comparative Evaluation of the Influence of Waste Vegetable Oil and Waste Animal Oil-Based Biodiesel on Diesel Engine Performance and Emissions. Fuel 2020, 280, 118613. [CrossRef]

26. Seffati, K.; Honarvar, B.; Esmaeili, H.; Esfandiari, N. Enhanced Biodiesel Production from Chicken Fat Using CaO/CuFe2O4 Nanocatalyst and Its Combination with Diesel to Improve Fuel Properties. Fuel 2019, 235, 1238-1244. [CrossRef]

27. Domínguez-Sáez, A.; Rattá, G.A.; Barrios, C.C. Prediction of Exhaust Emission in Transient Conditions of a Diesel Engine Fueled with Animal Fat Using Artificial Neural Network and Symbolic Regression. Energy 2018, 149, 675-683. [CrossRef]

28. Duda, K.; Wierzbicki, S.; Śmieja, M.; Mikulski, M. Comparison of Performance and Emissions of a CRDI Diesel Engine Fuelled with Biodiesel of Different Origin. Fuel 2018, 212, 202-222. [CrossRef]

29. Kirubakaran, M.; Arul Mozhi, S.V. Eggshell as Heterogeneous Catalyst for Synthesis of Biodiesel from High Free Fatty Acid Chicken Fat and Its Working Characteristics on a CI Engine. J. Environ. Chem. Eng. 2018, 6, 4490-4503. [CrossRef]

30. Karuppan, D.; Muthu Manokar, A.; Vijayabalan, P.; Sathyamurthy, R.; Madhu, B.; Mageshbabu, D.; Bharathwaaj, R.; Jenoris Muthiya, S. Experimental Investigation on Pressure and Heat Release HCCI Engine Operated with Chicken Fat Oil/Diesel-Gasoline Blends. Mater. Today Proc. 2020. [CrossRef]

31. Rao, K.S.; Ramakrishna, A.; Rao, P.V. Effect of Fuel Injection Pressure on Performance and Emission Characteristics of DI-CI Engine Fueled with Chicken Fat Biodiesel. Int. J. Therm. Technol. 2013, 3, 53-59.

32. Wyatt, V.T.; Hess, M.A.; Dunn, R.O.; Foglia, T.A.; Haas, M.J.; Marmer, W.N. Fuel Properties and Nitrogen Oxide Emission Levels of Biodiesel Produced from Animal Fats. J. Am. Oil Chem. Soc. 2005, 82, 585-591. [CrossRef]

33. Kirubakaran, M.; Arul Mozhi Selvan, V. A Comprehensive Review of Low Cost Biodiesel Production from Waste Chicken Fat. Renew. Sustain. Energy Rev. 2018, 82, 390-401. [CrossRef]

34. Behçet, R. Evaluation as Fuel Diesel Engine of Methyl Esters Derived from Waste Animal Fats. Energy Explor. Exploit. 2015, 33, 227-242. [CrossRef]

35. Arbune, J.; Manatkar, S.; Koparde, N.; Hingane, M.; Ghadge, A. Performance and emission analysis of biodiesel (jatropha+chicken fat) on diesel engine. IJRET 2014, 2, 81-90. 
36. Gurusala, N.K.; Selvan, V.A.M. Effects of Alumina Nanoparticles in Waste Chicken Fat Biodiesel on the Operating Characteristics of a Compression Ignition Engine. Clean Technol. Environ. Policy 2015, 17, 681-692. [CrossRef]

37. Mohiddin, M.N.; Saleh, A.A.; Reddy, A.N.R.; Hamdan, S. A Study on Chicken Fat as an Alternative Feedstock: Biodiesel Production, Fuel Characterisation, and Diesel Engine Performance Analysis. IJAME 2018, 15, 5535-5546. [CrossRef]

38. Mikulski, M.; Ambrosewicz-Walacik, M.; Duda, K.; Hunicz, J. Performance and Emission Characterization of a Common-Rail Compression-Ignition Engine Fuelled with Ternary Mixtures of Rapeseed Oil, Pyrolytic Oil and Diesel. Renew. Energy 2020, 148, 739-755. [CrossRef]

39. Hunicz, J.; Matijošius, J.; Rimkus, A.; Kilikevičius, A.; Kordos, P.; Mikulski, M. Efficient Hydrotreated Vegetable Oil Combustion under Partially Premixed Conditions with Heavy Exhaust Gas Recirculation. Fuel 2020, 268, 117350. [CrossRef]

40. Piaszyk, J. Animal Fat (Tallow) as Fuel for Stationary Internal Combustion Engines. Ph.D. Thesis, School of Mechanical Engineering, University of Birmingham, Birmingham, UK, 2012.

41. Heywood, J.B. Internal Combustion Engine Fundamentals, 2nd ed.; McGraw-Hill Education: New York, NY, USA, 2018; ISBN 978-1-260-11610-6.

42. Suresh, M.; Jawahar, C.P.; Richard, A. A Review on Biodiesel Production, Combustion, Performance, and Emission Characteristics of Non-Edible Oils in Variable Compression Ratio Diesel Engine Using Biodiesel and Its Blends. Renew. Sustain. Energy Rev. 2018, 92, 38-49. [CrossRef]

43. Erdoğan, S.; Balki, M.K.; Aydın, S.; Sayın, C. Performance, Emission and Combustion Characteristic Assessment of Biodiesels Derived from Beef Bone Marrow in a Diesel Generator. Energy 2020, 207, 118300. [CrossRef] 